\title{
Vulnerability and Poverty During Covid-19: Religious Minorities in Nigeria
}

The Covid-19 pandemic has had direct and indirect effects on religiously marginalised groups, exacerbating existing inequities and undermining ambitions for those 'furthest behind' to be reached and supported through the Sustainable Development Goals (SDGs). The intersection of religious identity, socioeconomic status, geographic location, gender, and age compound vulnerability to violence and its impacts. This policy briefing, written by Dr Joanna Howard, Professor Oluwafunmilayo Para-Mallam, Dr Plangsat Bitrus Dayil, and Dr Philip Hayab, draws on research into the experiences of the pandemic by religious minorities living in Kaduna and Plateau states in Nigeria and finds that the pandemic deepened pre-existing ethno-religious fault lines. Exacerbated by ongoing insecurity, it contributed to increased poverty, with women particularly affected, and worsening mental health, with people experiencing fear, frustration, and depression. There are also long-term consequences for development; for example, on children's education.

\section{Key messages}
- Perceptions of religious discrimination, marginalisation, and persecution are felt in both Christian and Muslim communities and are rooted in historical, cultural, and political factors.

- The pandemic has deepened pre-existing ethno-religious fault lines widely perceived by research participants to persist due to government inattention to underlying contentions, as well as the state's discriminatory response patterns.

Women and girls, especially those living in poor areas and in camps for internally displaced persons (IDPs), have been disproportionately affected due to an increased care burden for the sick, gender-based violence, and lack of state support.

- Government inaction to reduce levels of insecurity, combined with a lack of well-supervised universal provision of relief to those in need during lockdown, heightened suffering and increased suspicion and division between religious minority and majority groups in both Kaduna and Plateau states.

- Government responses to the pandemic were characterised by systemic and operational lapses, often politicised, which strengthened perceptions of religious discrimination and marginalisation.

- The waning of trust within communities that experienced a series of attacks during the lockdown, and the perceived inability of government to take proactive and protective measures to secure vulnerable populations, threatens to impede post-Covid inter-religious harmony.

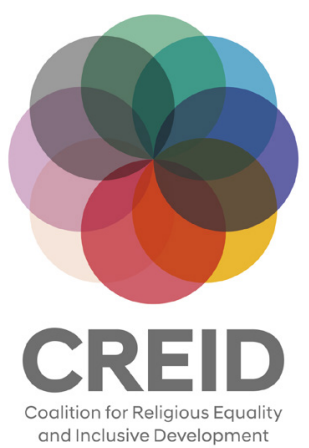


Nigeria context - religious minorities, insecurity, and Covid-19

In the context of a steady increase of violence and insecurity in Nigeria, both Plateau and Kaduna states have witnessed decades of violent ethno-religious conflicts and both Christian and Muslim participants in our research reported religiously motivated attacks and political exclusion. The situation in these states is complicated and complex for a variety of reasons:

- Plateau state is one of only two states in Nigeria (of a total of 19), whose populations and governments are predominantly Christian, consisting of mainly non-Hausa/non-Fulani indigenous ethnic groups. In Kaduna, Christian peoples populate the southern part of the state, while Muslims constitute a numeric majority in its central and northern zones. They are also politically dominant in the state.

- Within the larger context of a predominantly Muslim northern Nigeria, Christians in Plateau and Kaduna states feel victimised by centuries of Islamic domination.

- Conversely, Muslims who have long settled in Plateau state and southern Kaduna often feel marginalised by Nigeria's indigene/ settler polarisation engineered by constitutional fault lines.

The nation's inability to manage its diversity, the competing quests for political power, and the struggle by various ethnic nationalities to protect and maintain cultural/religious distance, continues to complicate efforts towards democratic consolidation. The implication is that in both states, Muslims and Christians lay claim to marginalisation and minority status for diverse reasons.

\section{Geopolitical competition for resource control, an Islamic state, restructuring, and secession}

After the return to democratic rule in 1999, 12 states in northern Nigeria declared the institution of Sharia Law in the year 2000. This was widely perceived as a protest reaction of the northern elite to the election of General Olusegun Obasanjo, the first Christian President and the first president from the south of Nigeria in 20 years (except for a brief six-month interim government led by Chief Earnest Shonekan). The end of 29 years of military rule (1966-99, with a four-year civilian rule between 1979 and 1983) witnessed an upsurge in sectarian conflicts around boundary and resource control, and ethno-religious divisions.

In 2009, Boko Haram, an Islamist fundamentalist sect which had become a subterranean separatist movement since 2002, launched a series of attacks on government agents and installations as well as on churches and Christian minorities in the northeast. This was the beginning of Boko Haram's violent insurgency against the Nigerian state. Boko Haram terrorists have since extended their attacks to Muslim moderates in opposition to their interpretation of Islam.

Following this, both the 2015 and 2019 elections were significantly infused with intense public rhetoric around ethno-religious contestations, indicating that identity politics have not abated, but 
rather, have intensified. These contestations are complicated further by conflicting geopolitical competition for resource control, the presence of an Islamic state, calls for restructuring and secession as well as rising crime, particularly kidnapping, cultism, ritual killings, and banditry.

Added to this is the impact of climate change and increased desertification on the livelihoods of pastoralists, and the fallout from intra-state civil strife in the Maghreb region, which have precipitated massive transhumance (seasonal movement of livestock). As a result, Muslim Fulani cattle herders, one of the world's largest nomadic groups, are moving southwards towards Nigeria's Middle Belt in search of pasture for their herds. Their practice of open grazing has resulted in frequent clashes with Christian farming communities who accuse them of damaging their crops, while the Fulani themselves claim to be attacked by gangs from these communities trying to steal their cattle. The situation is aggravated by the proliferation of small arms and light weapons which a Presidential Committee in 2016 linked to the infiltration of militants and mercenaries across Nigeria's northern borders after regime collapse in Libya and Mali.

Beyond these clashes over resources, many Fulani pastoralists have joined Islamist militant groups (for myriad reasons) and, as a result, Fulani-attributed attacks have become more violent - for example, rape, abduction, and murder - and more sectarian in nature for example, targeting Christian religious days and sites.

In Kaduna and Plateau states, where violence against farming communities has escalated, Christians are particularly badly affected by both Fulani herder and Islamist militant attacks on their villages. According to the Humanitarian Aid Relief Trust, over 1,ooo Christians were killed in such attacks between January and November 2019.

The situation has not been helped by a lack of prosecution against perpetrators of violence and little or no protection from the federal or state governments. Additionally, President Muhammadu Buhari, who is himself Fulani, is sometimes perceived as being 'soft' on the herders, which deepens political and ethnic divisions.

\section{Impact of the pandemic on violence and insecurity}

Atrocities have continued since the start of the pandemic:

- Ancha and Hukke villages in Miango district of Bassa Local Government Area (LGA) of Plateau state were attacked in April 2020 and, subsequently, the villagers were displaced by Fulani militia.

- An attack was carried out on 15 April 2020 in Bassa LGA where suspected herdsmen killed about nine people and razed over 200 houses.

- In southern Kaduna state, herdsmen militia attacked a community on 11 May 2020, killing many and displacing others.

- A day after this attack, militants - who often pose as herdsmen killed 17 people in Gonan Rogo village in Kajuru LGA, Kaduna state. 
It is important to note that these attacks have also been attributed to the progressive dislodgement of Boko Haram terrorists by the Nigerian military from the northeast, and their spread to other parts of the country.

Consequently, it has often been difficult to distinguish between the activities of herders and Islamic militants, who sometimes work in collusion, thus adding to the complexity of the conflicts. As a result of widespread and severe ethno-religious violence, the Plateau State Government established the Plateau State Peace Building Agency (PSPBA) in 2016. Kaduna state set up a similar agency modelled on the Plateau example. However, although the PSPBA has recorded some successes, the agency suffers from institutional deficiencies that limit its impact.

\section{Frustration with how federal and state governments have managed Covid-19}

For a country of over 200 million people, the spread of Covid-19 has been quite controlled, and various measures were put in place by federal and state governments. As of 14 October 2021, there were 208,630 confirmed cases and 2,767 deaths (Nigeria Centre for Disease Control).

\section{Methodology note}

These findings are drawn from 12 participatory inquiry groups, drawings, reflections, ranking and scoring matrices, and 16 semi-structured interviews.

Research participants, composed of people living in poverty, were brought together in separate groups of men and women of each religious minority. The selected sites were towns sheltering IDPs in Plateau and Kaduna states. The methods also allowed for the experiences of comparator groups to be analysed, i.e. those also living in poverty but of the majority religion in their area.

Inquiry groups in each site began with a River or Road of Life exercise, which enabled participants to one-by-one share the stories of their lives over the last 18 months, from before the pandemic to their experiences of life in the shadow of Covid-19. Participants drew or placed pebbles, stones, and leaves to represent elements of their stories. This exercise enabled pre-literate or semi-literate individuals to communicate without the inhibition that a writing-based activity could have caused. It also prompted group discussion of the issues and was followed by a PRA matrix ranking exercise to identify the group's most pressing issues. Using beans or small stones, the participants registered the severity of each challenge in their life on a scale of 0 to 3 . During discussions, major themes emerged, prompted with additional questions from the researchers. Semi-structured interviews were conducted with selected participants to deepen or complement the inquiry group data.

The use of the inquiry group and the Participatory Rural Appraisal (PRA) Matrix Ranking were eye-openers for us, the researchers. Although we were a bit apprehensive at first, most especially when we had considered using the 'road of life' for the men, we soon realised that they not only grasped the concept but also appreciated it in a manner we had least expected. Their explanations and emotions were quite illuminating. (Facilitator working with Christian men, Plateau state) 
The federal government, through the Nigeria Centre for Disease Control, imposed strict lockdown measures to curb the spread, including limiting inter- and intra-state travel and stay-at-home orders. These measures disproportionately affected low-income earners in the informal economy as well as seasonal workers in rural and urban areas, leading the federal government to initiate a distributary Covid-response programme. In fact, many risked infection, harassment, violent attack, and kidnapping by pursuing their livelihoods so they could feed their families. This happened because these most vulnerable minorities are not afforded sufficient protection by local statutory service providers.

Religiously motivated violence and perceived discrimination has further blocked their access to the necessary services to stay healthy during the pandemic. As the imposed lockdown continued, many youths became frustrated by how palliative measures, such as emergency food aid, appeared to be based on geopolitical and ethno-religious considerations. In both Plateau and Kaduna states, government reserves of supplies were attacked and looted during protests.

Some religious leaders also fomented frustration. Among the Muslim community, particularly in northern Nigeria, mistrust towards lockdown measures, including the closure of places of worship, derives primarily from age-long suspicion towards global health institutions and practices. In Jos, a popular Muslim cleric, Sheikh Jingir, led a public outcry among adherents against government prohibition of congregational gatherings, calling it a western ploy to attack Islam. Also, the high-handed response of security agencies against protesters further compounded the situation in Jos, as in other parts of the country.

In Kaduna and Plateau states, Covid-19 also increased the risk of violence and attacks on farming communities as nomadic herdsmen have continued grazing their livestock almost unchecked in the rural communities of Kajuru and Bassa. Due to the restrictions placed on human movement and the inability of statutory authorities to restrict grazing in rural areas, destroyed farmlands and produce were often a source of tension in addition to pre-existing religious mistrust.

\section{Key findings}

Ongoing herder attacks, militancy, violence, and insecurity in Plateau and Kaduna states continue to drive the displacement of villagers into urban areas, away from their farms and livelihoods, and have resulted in loss of life, ongoing insecurity, and trauma. This has exacerbated the impact of the pandemic on all, and especially on Christian families who have been targeted by the attacks and continue to live in fear. All the Christian men and women participants identified their most pressing issue during the pandemic as physical insecurity.

In both sites, there has been little state or local governant intervention to mitigate the impact of either the insecurity or the pandemic, which has resulted in heightened vulnerabilities. During lockdown in both states, internally displaced Christians faced constant fear, hunger, and distress. Women and children are disproportionately represented in most IDP camps. Christian women were also exposed to pressure to exchange sex and other forms of sexual exploitation for financial
Ongoing herder

attacks, militancy, violence and insecurity continue to drive displacement, which has exacerbated the impact of the pandemic, especially on Christian families 
benefits. Internally displaced Muslims also experienced deprivations, particularly those Muslim women who struggled alone to feed their children with no support from government.

Participatory ranking exercises identified that for the majority, assistance has come from non-governmental organisations (NGOs) and host communities, with little or none of the government pandemic assistance reaching them. Christian communities highlighted discrimination from government and security personnel in responding to security challenges and in the distribution of aid during the pandemic. The following presents specific findings grouped according to the priority themes that emerged in the research.

\section{Absence of state support exacerbates economic impacts, particularly on women}

The Covid-19 pandemic has devastated the livelihoods of those most vulnerable to crisis. This is particularly so for the urban and rural poor who, like most participants in this study, rely principally on seasonal work, farming, and vegetable/fruit market gardening. Local transport and markets ceased during the lockdown, which left them without income. The impact of the pandemic has been amplified for those who are also disadvantaged by their religious identity. For example, Christians whose villages were attacked during the lockdown were displaced and, as a result of the ongoing insecurity, cannot return to their farms to cultivate food.

The economic impact of Covid-19 is disproportionately felt by women, especially those responsible for children. Some Christian women reported that their husbands had left their families to seek work in Abuja and Lagos, as rural economies contracted and township jobs were lost, leaving them to manage alone during the lockdown. Other Christian women told of how their husbands, sons, and brothers had been killed in the attacks on villages. The situation for IDPs in both states is particularly challenging and is most extreme for marginalised religious minorities who face social stigma and government discrimination with regard to assistance, as well as the struggle to get by while living as refugees during the pandemic.

In all the discussions, the absence of state or federal intervention was clear with no mention of economic aid for losses of income due to violent crises or the pandemic. Women, who are mainly involved in the cultivation of perishable goods, are particularly affected by events that prevent them tending their crops or from movement to enable the sale of their perishable goods in the major markets. Both Muslim and Christian communities spoke of persistent hunger and of managing on one meal a day, especially where the household is headed by a widow. The vulnerability of widows and children is heightened by the loss of an income earner and the absence of social safety nets and familial support.

\section{Religious discrimination around the distribution of aid during the pandemic}

Religious identity, political affiliations, and corruption shape the level of government assistance in the form of food stuff, cash gifts, and loans received during the pandemic. The uneven distribution of aid
The economic impact of

Covid-19 is disproportionately felt by women, especially those responsible for children 
Figure 1 Regional distribution of beneficiaries of the conditional cash transfer, 9 April 2020

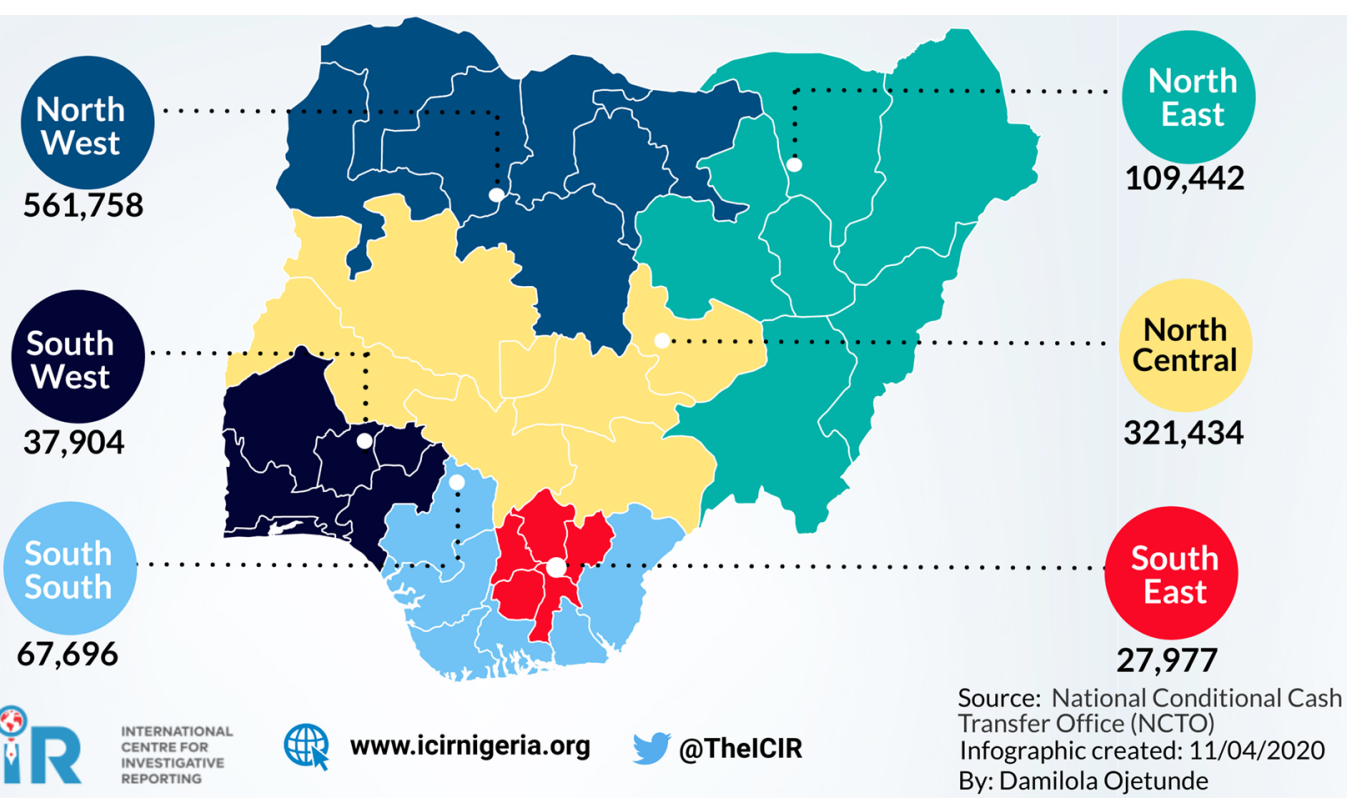

Source: @International Centre for Investigative Reporting (ICIR), reproduced with permission.

and social protection exacerbated the economic impact on religious minorities who had little or no access to government assistance. For example, Christian men in Kaduna state mentioned that any help to their communities during the lockdown came from churches and NGOs like the Red Cross and the Resilient Aid Dialogue Initiative (RADI), but not from the government. They perceived that government 'Covid-19 loans' were reaching Muslims but not Christians, which made them feel politically and economically mistreated. However, allegations of marginalisation in the distribution of aid and social protection, especially cash transfers and foodstuff, were nationwide. Some studies and commentaries allude to systemic and operational lapses, such as the lack of a verifiable database of poor and vulnerable people, and politicians hijacking the process as reasons rather than deliberate attempts by government to discriminate. On the other hand, figures showing the distribution of cash transfers indicate wide regional disparities, as shown in Figure 1.

Local politicians are perceived to deploy security forces and distribute aid along ethno-religious lines. Christian respondents in Kaduna described such discrimination in the distribution of aid (referred to as 'palliatives' by research participants) during the pandemic as follows:

They are not given because in our community, the [proportion of] Christian[s in the] population is higher and so the palliatives are not brought here... in a 100 per cent of people our Christian population is 98 per cent... They say they will share for all communities but when this sharing is made, they share among the politicians who in turn share based on religion or faith of the people. I know how this is done as those that receive these palliatives tell me. 
Impact of the pandemic on mental health and general wellbeing

The combination of hunger, uncertainty, and insecurity has been devastating for religious minorities in both states. Covid-19 infection was unknown to them, but the impacts of the violent attacks and the loss of life and livelihoods intensified during the lockdown, provoking even greater despair and depression, particularly amongst Christian respondents. Researchers in Kaduna observed that participants

appear emotionally broken, psychologically demoralised, and poor, representing anxiety of an ambiguous future caused by the loss of husbands, children, wives, relatives, and their sources of livelihood. The reflection stems from the visible reality that most of the participants became emotional while telling their stories with most of them sorrowful how that they had not eaten all day and did not know where their next meals were going to come from.

Nigerian households in rural and low-income urban/semi-urban areas tend to be overcrowded. Tensions within crowded households have led to reports of domestic violence and abandonment, impacting on both Muslim and Christian women. Male seasonal workers and people on daily/weekly wages from petty trading and other forms of informal sector jobs experienced frustration from the loss of income incurred by the lockdown. This is reflected in increased incidents of domestic violence, particularly intimate partner violence and violence against children and domestic servants. Due to the economic reliance on their husbands, many women endure maltreatment and abuse.

\section{Insecurity during the lockdown}

Most participants had experienced insecurity with kidnappings, murders, and assaults happening in their villages, or on the roads or in the fields. However, the ongoing targeting of Christian villages in northern Plateau and southern Kaduna states, and the lack of a coordinated response by the state to protect Christian populations has created extreme poverty and insecurity for these groups in particular. The lack of protection and security for Christian villages in Kaduna and Plateau exacerbates the impact of Covid-19. They have been displaced from their source of livelihood and must risk their lives if they return to cultivate food - but if they do not, their children will starve.

Christian participants reported that soldiers appear indifferent to their communities and fail to pre-empt or repel the attacks. Attacks on Christian villages during the pandemic were felt to be religiously motivated. A Christian respondent said that 'this has everything to do with my faith, why [else are they] burning my church?'.

The lack of state protection has led some Christian communities, for example in Kaduna state, to organise their own security, ultimately endangering the lives of their young people who take on the task of keeping watch over their community at night and repelling attacks. The government requirement that communities do not take the law into their own hands has resulted in these vigilantes being disarmed and arrested by state authorities. However, since security agencies have yet to apprehend or prosecute perpetrators of violent attacks on 
communities, this reinforces beliefs in a highly selective justice. It is compounded by the control of security apparatus at the federal level, and a highly skewed number of appointments into the top hierarchy of security units in the country being awarded to those hailing from the Muslim north. Overall, this has strengthened perceptions of discrimination and persecution within Christian communities.

Some Muslims have also been displaced through Boko Haram attacks in the north of Plateau state and are also impacted, as they have been living in cramped and challenging circumstances as IDPs during the pandemic. It is important to note that moderate Muslim communities who do not share extremist Islamist views are increasingly being exposed to violent attacks, including kidnapping and banditry in different parts of Nigeria.

\section{Impact on schooling and education}

The loss of access to schooling for children has been exacerbated by the lockdown and attacks on Christian villages, where schools and churches have been burnt down and teachers have fled.

Populations in low-income and rural areas do not have the devices and services needed for online schooling. This impacts negatively on children from poor communities, particularly on public school attendees and IDPs, both Muslim and Christian. In the longer term, Covid-19 will have lasting impacts on poor families and will prolong and deepen the impact of the lockdown.

\section{Policy recommendations}

In Plateau and Kaduna states, intractable security challenges have intersected with the deprivations of the pandemic and lockdown measures to create enormous hardship, poverty, hunger, and loss of life amongst religious minority groups. Since Covid-19 began, there have been increased cases of violence and encroachments on religious rights, as evidenced by Christian men and women who took part in our research in Plateau and Kaduna, and the comparator group of Fulani Muslims in Miango, Plateau.

We recommend that:

- Policies are sensitive to the intersections of religious with other inequalities (e.g. class, gender, age), within and beyond the context of Covid-19, because the inequalities faced by minorities during the pandemic were already present, but worsened with the onset of the pandemic. This is critical for the longer-term recovery of these groups, who otherwise face slipping deeper into intergenerational poverty.

- Government at federal and state levels check and ensure all policies explicitly support women, both as members of religious minorities and as victims of gender discrimination within their religious groups and families as well as in wider society. Issues such as women's lack of education and lack of financial independence are an important starting point.

\section{Christian}

participants

reported that

soldiers appear

indifferent to their

communities and

fail to pre-empt or

repel attacks 
- The federal government develops a verifiable database of vulnerable populations in all parts of the country to facilitate a more coordinated and systematic response to pandemics and other health emergencies.

- Emergency response efforts in Nigeria adopt holistic measures to include community-driven disaster risk management and mental health treatments for depression as well as other post-traumatic stress disorders.

- Emergency response programmes should recognise and address the gender-differentiated status of men and women, and their vulnerability to socioeconomic and physical shocks.

\section{Plateau state research policy recommendations:}

- The passage into law of the bill allowing states to have state police with a strong community policing component at local government and village levels.

- Ensure a reorganisation of those heading the security apparatus for inclusion and social justice in addition to comprehensive security sector reform to promote transparency and accountability.

- Strengthen the PSPBA to facilitate inter-faith community dialogues and collaborative activities among Muslim and Christian groups.

- Strengthen the existing nomadic education curriculum and provision of incentives and support to herders who may wish to adopt modern techniques of rearing animals. Provide pastoralists who wish to become sedentary with land, training, and other inputs to facilitate the process. Ban open and night grazing in residential and farming areas.

- Enforce the Violence Against Persons Prohibition Act (2015) to expedite the trials of person crimes by an independent judiciary.

- Institutionalise truth and reconciliation processes in all reintegration plans and promote community-based psycho-social support, trauma counselling sessions, and support to victims of these attacks, particularly the IDPs.

- Organise a comprehensive state-sponsored resettlement programme to reintegrate displaced communities back to their homelands and into normal life, and deploy an adequate internal security management system to prevent further attacks.

- Set up an integrated response system to health emergencies that incorporates a cross-section of emergency responders from different sectors of the economy.

- Promote peace education through the establishment of platforms that promote inter-religious dialogue and harmony. 


\section{Further recommendations to improve community} livelihoods and well being:

- The Plateau State Government should encourage and support entrepreneurs to diversify into processing agricultural products to enhance the shelf life of agricultural produce, to create more employment opportunities and secure rural farmers' livelihoods.

- Police, military, customs, and immigration services should ensure that safe transportation of goods to markets across state borders are unhampered by crises, while adopting measures to detect and stop the movement of small arms and light weapons and criminal elements across internal and national borders.

- Farmers should be encouraged to set up cooperatives to enhance their collective bargaining power and ensure fair pricing for their goods.

- The state government should create or strengthen social safety nets and inclusive health insurance for the indigent, particularly widows and orphans.

\section{Kaduna state research recommendations:}

- The local and the international communities must double their efforts towards ending inter-religious/intergroup conflicts in all guises if Nigerians of all walks of life and socioeconomic backgrounds are to reach their full potential. The Kaduna State Government needs to safeguard security by promoting peace and conflict resolution mechanisms for inclusive and sustainable development in the rural and urban areas.

- Equity and equality of all citizens should not only be enshrined in statutory books but must be deliberately implemented in government policies and programmes to support inclusivity.

- Establish community policing committees in all local government areas, wards, and districts comprising state security personnel and vigilante groups to safeguard the security and sanctity of human life. This is likely to boost public confidence in government security efforts. Citizen confidence will also increase with the apprehension and prosecution of perpetrators of violent attacks.

- Both federal government and the Kaduna State Government should strengthen the preventive, detective, and prosecutorial capabilities of formal security and law enforcement agents to eliminate banditry and kidnappings of innocent people for ransom and to restore peace among the communities. This would also enable IDPs to return safely to their homes, as they strongly wish to do, to pursue their economic activities, including agriculture.

- There is a need for social protection and economic empowerment, including skills acquisition for men and women, in the communities of Kajuru and Rigasa, with convincing efforts to ensure peace and security in the area. Without peace there will be no development.

- Ensure IDPs forced to leave their villages are resettled and guaranteed adequate security to enable them to farm and live normal lives. 


\section{Further reading}

Agbedo, Onyedika et al. (2020) 'FG's COVID-19 Palliatives: Why Nigerians Are Not Feeling the Impact', The Guardian [Nigeria], 8 August (accessed 12 October 2021)

Ambe-Uva, T. (2010) 'Identity Politics and the Jos Crisis: Evidence, Lessons and Challenges of good Governance', African Journal of History and Culture (AJHC) 2.3: 42-52

APO Group (2021) 'Africa News Coronavirus - Nigeria: COVID-19 update', africanews (accessed 12 October 2021)

APPG for International Freedom of Religion or Belief (2020) Nigeria: Unfolding Genocide? An Inquiry by the UK All-Party Parliamentary Group for International Freedom of Religion or Belief, London: APPG for International Freedom of Religion or Belief (accessed 12 October 2021)

Cissé, M.G. (2020) 'Understanding Fulani Perspectives on the Sahel Crisis', Spotlight, African Center for Strategic Studies, 22 April (accessed 12 October 2021)

Cox, C. and Thomas, D. (2019) 'Your Land or Your Blood': The Escalating Persecution and Displacement of Christians in Northern and Central Nigeria, London: Humanitarian Aid Relief Trust (accessed 12 October 2021)

Ezeah, P. (2020) “"Chaotic” Distribution of COVID-19 Pandemic Lockdown Palliatives in Abuja, Nigeria', ASSET (accessed 12 October 2021)

Gofwen, R. (2012) 'A Historical Overview of Ethno-Religious Conflicts in Plateau State: Government Intervention and Strategies', in O.J. Para-Mallam (ed.), Finding Durable Peace in Plateau State, Kuru: National Institute Press

Hankivsky, O. and Kapilashrami, A. (2020) 'Intersectionality Offers a Radical Rethinking of Covid-19', BMJ 20.09: 26

Hassan, I. (2020) 'Herdsmen Kill 17 in Kaduna Village', Vanguard News, 13 May (accessed 1 September 2020)

Hoechner, H. (2020) 'In Northern Nigeria, Distrust Jeopardises the Response to Coronavirus', The Conversation, 15 April (accessed 12 October 2021)

International Crisis Group (2018) Stopping Nigeria's Spiralling Farmer-Herder Violence, Africa Report 262, 26 July (accessed 12 October 2021)

Open Doors \& Ireland (2021) 'Written Evidence Submitted by Open Doors UK \& Ireland (IRNo012)’ (accessed 12 October 2021)

Ryan, N. and Al-Ayadi, A. (2020) 'A Call for a Gender-Responsive, Intersectional Approach to Address Covid-19', Global Public Health 15.9: 1404-12

Ufua, D.E.; Osabuohien, E. and Ogbari, M.E. (2021) 'Re-Strategising Government Palliative Support Systems in Tackling the Challenges of COVID-19 Lockdown in Lagos State, Nigeria', Global Journal of Flexible Systems Management 22: 19-32 (accessed 12 October 2021) 


\section{Credits}

This CREID Policy Briefing was written by Dr Joanna Howard (Institute of Development Studies), Professor Oluwafunmilayo Para-Mallam (National Institute for Policy and Strategic Studies), Dr Plangsat Bitrus Dayil (University of Jos), and Dr Philip Hayab John (Kaduna State College of Education). It was edited by Emilie Wilson and produced as part of the Coalition for Religious Equality and Inclusive Development (CREID). CREID is funded by UK Aid from the UK government and provides research evidence and delivers practical programmes to redress the impact of discrimination on the grounds of religion or belief, tackle poverty and exclusion, and promote people's wellbeing and empowerment.

CREID Policy Briefings are published by the Institute of Development Studies (IDS) and aim to share key research findings and make practical recommendations for policymakers and donors.

The opinions expressed are those of the authors and do not necessarily reflect the views or policies of IDS or the UK government.

\section{(cc) BY This is an Open Access publication distributed under the} terms of the Creative Commons Attribution 4.0 International licence (CC BY), which permits unrestricted use, distribution, and reproduction in any medium, provided the original authors and source are credited and any modifications or adaptations are indicated.

DOI: 10.19088/CREID.2021.013

Institute of Development Studies, Brighton BN1 9RE, UK

$T+44(0) 1273606261$

$\mathrm{F}+44(0) 1273621202$

E creid@ids.ac.uk

Wwww.creid.ac

T @CREID_Dev

CREID partners



institute of development studies

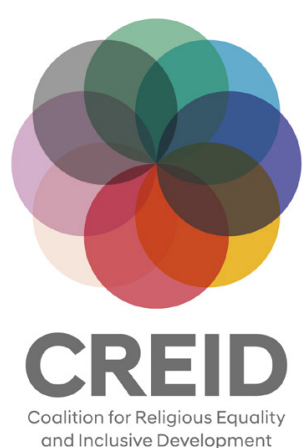

